\title{
Between Impact and Delusion: The Role of American Think Tanks in Political Decision-Making - A Case Study of American Policy towards the Russian Federation after Annexation of Crimea
}

\author{
Między wpływem a ułudą: Rola amerykańskich think tanków \\ w kształtowaniu polityki Stanów Zjednoczonych wobec Federacji Rosyjskiej \\ po aneksji Krymu
}

\section{- Abstrakt •}

Celem artykułu jest zbadanie, w jakim stopniu czołowe amerykańskie think tanki wpływały na politykę Stanów Zjednoczonych wobec Federacji Rosyjskiej po aneksji Krymu w marcu 2014 roku. Analizie porównawczej zostały poddane Brookings Institution, Carnegie Endowment for International Peace oraz Atlantic Council. Ich działalność zestawiono z modelem wpływu think tanków przedstawiającym się wedle następującego schematu: określenie idei i zagadnień, dostarczanie politycznych alternatyw, kształtowanie procesu decyzyjnego. Autor osadził wyniki swojej analizy w szerszej dyskusji dotyczącej zmian zachodzących w porządku światowym oraz samym systemie demokracji liberalnej.

Słowa kluczowe: think tanki, bezpieczeństwo; Federacja Rosyjska; Ukraina; Stany Zjednoczone

\section{- Abstract •}

The aim of this paper is to examine to what extent the leading US think tanks influenced the US policy towards the Russian Federation after annexation of Crimea in March 2014. Comparative analysis was performed on three entities - the Brookings Institution, the Carnegie Endowment for International Peace and the Atlantic Council. Their respective activity has been placed against the model of think tank impact, which is composed of the following elements: framing of key ideas and issues - providing policy alternatives - shaping of decision-making process. The author has positioned the results of his analysis within a larger discussion on changes in the global order and the system of liberal democracy itself.

Keywords: think tanks; security; Russian Federation; Ukraine, United States 


\section{What are Think Tanks and How to Study Them?}

Discussions of the condition of modern think tanks are primarily concerned with analysis of contemporary liberal democracy which, as it develops, becomes an unbelievably complex and increasingly confusing system. Voting in elections is no longer the center of our interests; while it is still the most important and the most spectacular act in the entire process of power transfer from the hands of the sovereign (the people) into the hands of its representatives (president, parliamentarians, council members) it is steadily decreasing in importance. In-between elections we are witness to a series of behind-the-scenes deals and games, which is how the process of influencing political parties, governments and the media is conducted. Such influence is sought by social movements, interest groups and also by expert circles - including think tanks, whose main goal is to promote a specific idea or vision of policy change (see Selee, 2013, p. 4). However, expert organizations are subject to the same negative trends as other actors in the democratic system ${ }^{1}$. Lack of a clear, thought-out and far-reaching mission or concrete concept of the method for achieving their goals as well as shallowing of the message are some of the issues plaguing modern think tanks according to researchers (see Selee, 2013, p. 4). This paper aims to verify whether, and if yes - to what extent, the three analyzed Washington based think tanks were able to clearly and thoughtfully influence the American political agenda during one of the most serious post-Cold War crises. The illegal annexation of Crimea by the Russian Federation surprised the global public opinion, including the entire US administration. It is therefore worth analyzing the reaction of think tanks to this geopolitical crisis in order to check if their impact on US foreign policy towards Russia was real, or existed merely in declarations.

James McGann, a renowned think tank researcher, defines them as organizations focused on political research and analysis, which have the task of advising in the domains of internal and foreign policy and explaining complex political issues to the general public (see McGann, 2007, p. 24). This definition itself presents a number of important functions of think tanks, ranging from expert research, through political advisory tasks to their educational function. Activity of the Brookings Institution, the Carnegie Endowment for International Peace and the Atlantic Council in the period after annexation of Crimea by the Russian Federation in February and March 2014 will be analyzed through the lenses of these

${ }^{1}$ Of course think tanks exist also in non-democratic systems. However, in this paper the author will focus solely on entities operating within the American political system. 
three functions. The three aforementioned think tanks have a number of common features. These organizations are not politically affiliated and non-partisan, they focus on international affairs and are the absolute frontrunners among think tanks of this nature, both in the US and in the world ${ }^{2}$.

Activity of think tanks in the US consists primarily in organization of public discussions, preparation of briefings at the US Congress, publishing analyzes and more in-depth policy papers, as well as media interviews being given by affiliated analysts and experts (see Selee, 2013, p. 4) 3 $^{3}$ A special feature in think tank operations is their default long-term perspective. The described organizations "a priori" assume a long-term vision of impact, as promotion of an idea in the political discourse to a position of influence often takes decades and is fraught with high risk of failure (see Selee, 2013, p. 6) ${ }^{4}$. At this point we reach the first major limitation in the conducted analysis. Contemporary policy making, especially in times of crisis - and the time after annexation of Crimea certainly was and remains such is governed by the short-term perspective. In other words, both politicians and the public opinion, including the media, are looking for "here and now", immediate answers. This, of course, leads to a conceptual conflict with the very foundational assumptions of how think tanks operate - i.e. with analyses based on in-depth research. This research is much more time-consuming than the social expectations allow before, in the public's opinion, results should be delivered. In the subsequent sections of the paper, we will check whether the considered think tanks were able to find the right compromise between the demand for a quick response and reliability of their analysis.

Measurement of their effectiveness and impact is another important aspect of studying think tank activities. Thus it is worth delineating the categories common

2 In the 2019 Global Go To Think Tank Index Report ranking compiled by the University of Pennsylvania, the three aforementioned entities are ranked in the following positions among think tanks focused on foreign policy and international affairs: the Brookings Institution: 1st, the Carnegie Endowment for International Peace: 2nd, the Atlantic Council: 14th (2019 Global Go To Think Tank Index Report).

${ }^{3}$ For the purposes of this paper, the author has made his own selection of public events and analyzes. Analysis of all publications or seminars of the discussed think tanks on the subject of US policy towards the Russian Federation or Ukraine would be impossible in this article simply for quantitative reasons.

${ }^{4}$ It is worth providing here the example of the Mont Pelerin Society, which brings together neoliberal economists such as Friedrich August von Hayek and Milton Friedman. This think tank was founded in 1947, while the period of hegemony of the neoliberal idea dates only to the late 1970s and early 1980s. In other words, it took over three decades of promotion of this idea to allow it to take its current hegemonic position in the economic discourse and political practice of many countries and international organizations. 
to the analyzed organizations that will be subject to the same research methodology. Andrew Selee proposes several models to be used in the analysis of these organizations.

The first framework aims to place think tank activities within a broader cycle, during which first ideas are formulated, only later to be followed by political change. This diagram is as follows:

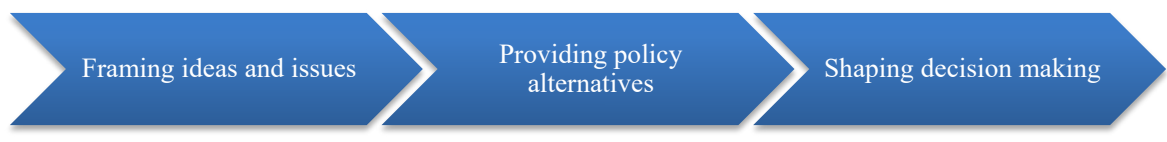

Source: Selee (2013), p. 9.

One can thus see that the above diagram goes, in a sense, through stages of political maturation, from initial idea through alternative narratives to action being taken. The key point is the last step, i.e. shaping of the decision-making process, which is reached by only few think tanks, usually politically affiliated or clearly partisan ones, as they have direct access to political decision-makers. Of course, the actual impact of these think tanks depends on which party is currently the dominant one in the United States administration 5 . In the later sections of the paper, the author attempts to position the three discussed think tanks along this cycle model.

Another model allowing to assess the impact and importance of an expert organization is the set of "5 strategic questions", which, according to Selee, are crucial for every major think tank and which permit to measure the effects of their actions:

5 The conservative Heritage Foundation usually has a privileged position when Republicans are in power, and the Center for American Progress - during a Democratic rule. To exemplify, Heritage played a key role in shaping US foreign policy after the terrorist attacks on the United States on September 11, 2001, while the Center for American Progress made a significant contribution to preparations of the important health care reform during the presidency of Barack Obama, known as Obamacare. 


\section{What does the organization want to achieve?}

What does the organization do that makes a unique contribution?

Who are the organization's key audiences and how does it reach them?

What resurces does the organization need and how can it develop them?

How does the organization evaluate impact and learn from its experience?

Source: Selee (2013), p. 13.

It is easily discernible that these questions form a logical whole, helping in development of think tank strategy; they focus primarily on issues related to management of an organization and measuring its effectiveness. Analyzing individual questions one can see that the goal a think tank wants to achieve should be viewed from the perspective of the overall political cycle. Large think tanks, thanks to their financial and personnel resources, are able not only to frame the ideas or define the political change they want to pursue, but also to take appropriate steps in that direction or present to the wider public the political alternative they want to achieve. Impact is also associated with uniqueness, directly affecting attractiveness of an organization. Thus, a think tank providing non-standard and interesting studies, concepts and ideas can more easily reach the audiences it is targeting - this holds true for politicians, experts and analysts, scientists, media as well as society as a whole. The most interesting and the most difficult aspect is measuring the impact of think tank activity. In fact, as Selee notes, organizations with a clearly defined goal can not only measure the immediate or short-term successes or failures of their activities but are also able to verify whether they are moving in the right direction as concerns their long-term vision (see Selee, 2013, p. 15). Although think tanks often operate day-to-day, evaluation from the perspective of weeks, months or years usually turns out to be the most valuable. In the present analysis, we use three sets of measurement categories: inputs (resources), outputs (events organized by a think tank, its publications, media citations, online statistics) and outcomes actual and tangible impact on political decisions (see Selee, 2013, p. 15).

With the appropriate methodological matrix to analyse the potential impact of think tanks as concerns United States policy towards the Russian Federation after the illegal annexation of Crimea in place, we can now move on to investigating what were the specific activities undertaken by the three organizations in response to this event. 


\section{Washington D.C. Case Studies}

The Brookings Institution is one of the oldest American think tanks, founded in 1916. According to popular opinion, it is not only the best and most influential think tank in the United States, but also in the world. The organization deals with a number of political topics, ranging from social policy through economics to foreign and security policy. In the Ukrainian context, Brookings had several highly influential analysts at its disposal in 2014, such as Fiona Hill and Steven Pifer, who were highly respected in the circles of Washington think tanks. Steven Pifer, as a former US ambassador to Ukraine, was from the very beginning regarded as one of main experts to appear in the American media. Fiona Hill, on the other hand, as an expert on Russian affairs, including policies of Vladimir Putin, often explained the significance of annexation of Crimea for Moscow in the context of Vladimir Putin's internal and foreign policy alike.

In addition to preparing a number of brief expert analyzes targeted at a specific group of analysts and political circles dealing with the US policy towards Russia (Brookings Institution. Russia), two public appearances by guests invited by the Brookings Institution were of significance. On February 28, 2014, so less than two days after the invasion of Russian troops in unmarked uniforms (so-called "little green men") on Crimea, the think tank hosted Foreign Minister of the Federal Republic of Germany, Frank-Walter Steinmeier. In his public speech Steinmeier criticized the actions of the Russian Federation in the international arena; he admitted however that the Western states would not be able to overcome the Ukrainian crisis without Russia (Transatlantic Ties for a New Generation: A Statesman's Forum with Frank-Walter Steinmeier). This was symptomatic, as Steinmeier showed the Washington public that the German policy of Russia first is completely out of tune with the sentiment prevailing at the time in Washington. It can be assumed that such a significant organization as the Brookings Institution did not only try to show American experts the aforementioned crack in the political stance of the West in a broad sense. It likely also attempted to indirectly influence the head of German diplomacy by exposing him to a number of opinions normally unavailable during official US-German bilateral talks. Thus Brookings turned out to be a unique institution, conducting its own public diplomacy at a time when German-American relations were in one of the toughest spots since $1989^{6}$.

${ }^{6}$ In 2013, Edward Snowden, former employee of the US National Security Agency (NSA), revealed that US intelligence has the German political elites under illegal surveillance, inter alia eavesdropping on private conversations of German Chancellor Angela Merkel. 
Another opportunity for Brookings to host a key actor in the transatlantic political life was the visit of the then head of NATO, Anders Fogh Rasmussen at the Brookings Institution headquarters on March 19, 2014. The official speech of Secretary Rasmussen, as well as the visit by Minister Steinmeier were an integral part of wider public activities undertaken by Brookings. Rasmussen's speech was significant for many reasons. First, as annexation of Crimea by the Russian Federation was underway, the head of the Alliance said in Washington, the US capital, that these events are "a wake-up call for the Euro-Atlantic community, for NATO, and for all those committed to a Europe whole, free, and at peace" (Revitalizing NATO: Address by Secretary-General Rasmussen). He added also that "we cannot take our (European) security for granted. We have seen other crises in Europe in the past decades (...) but this is the gravest threat to European security and stability since the end of the Cold War" (Revitalizing NATO: Address by Secretary-General Rasmussen). This exemplifies how a think tank becomes an agora for statements of historical significance - in this case, a place where representatives of the Western world present their point of view to the global public in a clear, transparent manner and draw the "red lines" that must not be crossed.

With these two case studies of activities conducted by the Brookings Institution, we can draw the conclusion that the main goal of the think tank is above all to frame key ideas and issues in international affairs for the American and global public opinion. In the analyzed period, Brookings focused only occasionally on providing political alternatives, and certainly did not influence the US decision-making process as concerned the official policy towards the Russian Federation.

The uniqueness of this think tank is primarily related to privileged access to important political figures, who were given the opportunity to present their positions to a wider public at Brookings headquarters. The audience for this type of events is typical of Washington - in addition to US government employees and army representatives, also representatives of diplomatic missions, experts from other think tanks and academics take part in such events hosted by Brookings. In this respect, as the public itself is very interested in events organized by the "best think tank in the world" there is no need for any particular "focusing" of their message. This directly affects another form of impact measurement for the Brookings Institution. In addition to the high number of citations of the organization's

7 Steven Pifer and director of the Brookings Institution, Strobe Talbott, made public appearances in which they supported the idea of supplying Ukrainians with defensive weapons. This was a position not in line with the official stance of Barack Obama's administration (see Pifer, Talbott, 2014). 
experts and their studies, the social and cultural context is equally important. Due to its reputation, the Brookings Institution acts in the American political arena as a flywheel, an initiator of discussions. The two speeches by Frank-Walter Steinmeier and Anders Fogh Rasmussen not only had phenomenal "timing", but also shaped opinions and informed the Washington public - first hand - of the positions of Germany and NATO regarding the conflict in question.

The next Washington think tank to be analyzed is the Carnegie Endowment for International Peace, which was founded in 1910 by Andrew Carnegie, a steel and metallurgy mogul who devoted the vast majority of his fortune to building various public and expert institutions. Carnegie Endowment is described as a "global think tank" with 5 offices scattered around the world and located in Washington, Brussels, Moscow, Beirut and Beijing. Due to the fact that Russian affairs are a focus topic of offices in Washington, Brussels and Moscow alike, it is difficult to determine which geography is the most important or the most representative as concerns activities of Carnegie Endowment globally in this respect. For the purposes of this article, we will focus on its Washington branch.

The experts from the American Carnegie Endowment that focused on relations between the West and Russia were Andrew S. Weiss and Eugene Rumer. They were responsible for organizing a series of expert events discussing the politics of the Russian Federation and its consequences in Central and Eastern Europe and in the world. The Carnegie Endowment has different expert activity tactics than the Brookings Institution. Instead of organizing large public events with important politicians, Carnegie focuses more on expert activities and organization of smaller seminars on more narrowly defined topics. One of the most important discussions organized by the Carnegie Endowment focused on whether the United States and the - broadly taken - West should supply weapons to Ukraine during the ongoing conflict at the eastern borders of this country. The debate Should the West Arm Ukraine? (Debate: Should the West Arm Ukraine?) took place in the Washington offices of Carnegie Endowment on February 19, 2015, a week after signing of the Minsk II Agreements (so-called Minsk II) between the President of the Russian Federation Vladimir Putin, President of Ukraine Petr Poroshenko, German Chancellor Angela Merkel and the French President François Holland. Minsk II concerned the conditions of a ceasefire between the so-called separatists and the Ukrainian army. Representatives of the think tanks analyzed in this paper took part in the debate on offering assistance for Ukraine in the form of armaments supplied by the West. John E. Herbst, representing the Atlantic Council and Steven Pifer of the Brookings Institution supported the position that the West should arm Ukrainians, while Eugene Rumer of the Carnegie Endowment for 
International Peace and Jeremy Shapiro of the Brookings Institution were against such a solution. The aim of this debate was to present the Carnegie Endowment as a "dialogue think tank", an arena to exchange expert knowledge. This is important because the fact-based, solid arguments of both sides to this discussion did not at the time get airtime in the American public debate ${ }^{8}$. This concerned above all the argument that providing non-lethal weapons would allow Ukrainians to defend themselves better against attacks of the so-called separatists and regular Russian Federation troops supporting them, which would increase the costs of aggression against Ukraine on the Russian side. On the other hand, opponents of this solution stressed the huge disparities between the Ukrainian and Russian forces as concerned troop numbers, ordnance and equipment available, training, and command capabilities. They argued that supplying weapons would not only not help in resolving the conflict, but in fact would exacerbate it, and stressed that the United States did not have allied obligations towards Ukraine.

Organization of this type of seminars was aimed at positioning the think tank as the place for a fairly elite discussion between Washington experts dealing with Russian affairs. To what extent through this type of activity the Carnegie Endowment is able to influence US foreign policy towards the Russian Federation is difficult to clearly determine and measure. Certainly, participation of a Department of State official or representative of the Pentagon in this type of debate allows to posit a hypothesis of possible transfer of this knowledge to policy makers. While the Carnegie Endowment was able to clearly define the idea it wanted to discuss during its event, the organization did not provide clear political alternatives. However, it is important that various positions were clearly articulated in the ensuing discussion and created the foundations for ready-made models that could be used in the future depending on how the events in Ukraine develop, and whether the agreements concluded in Minsk are respected. As in the case of the Brookings Institution, the Carnegie Endowment has a highly specific and almost identical audience. This stems not only from the similarly defined focus areas of the two think tanks, but also the geographical proximity of both'.

A certain unique feature of the Carnegie Endowment for International Peace deserves some attention - namely, a series of targeted projects with a related schol-

${ }^{8}$ The topic of the Russian-Ukrainian conflict quickly ceased to be the most important issue in the United States political arena. American discussions on domestic policy (the problem of the US police abusing power against black citizens) and the threat posed by the so-called Islamic state (ISIS) were the main media topics in 2014 and 2015.

9 Both think tanks are in fact located on the same in Washington (Massachusetts Avenue), at a distance of about $250 \mathrm{~m}$ form each other. 
arship and grant system that are part of their daily activity. For example, the think tank runs a project dedicated to Euro-Atlantic security under the name EASI (Euro-Atlantic Security Initiative). This project has two dimensions - on the one hand, a "council of wise men" of sorts was formed, made up of experienced politicians and diplomats who have been working for years to foster cooperation between the United States, Europe and the Russian Federation ${ }^{10}$. On the other hand, the project envisages building a network of new generation experts that would also work to improve cooperation and understanding between the West (US, EU) and the Russian Federation. On top of expert seminars and conferences, the project involves the award of grants for research focused on areas fostering the spirit of cooperation and understanding. This project component aims for long-term effects based on generational experience of young people who already have a certain position and knowledge in this field. These types of projects are not by their nature enjoying much airtime in the media, they are not intended to promote individual think tank experts. Instead, they are focused on a very specific analytical aspect and on building a true global network, which is of great importance for every significant think tank working in international affairs.

The last think tank discussed in the present paper is the Atlantic Council, an expert organization founded in 1961 to improve the relationship and exchange ideas between the United States and Europe. Damon Wilson and John E. Herbst are the main experts of this think tank dealing with current US-Russian relations, in particular as regards the Ukrainian context. It is an organization significantly different from both the Brookings Institution and the Carnegie Endowment for International Peace. First of all, it is much younger than the think tanks mentioned earlier and is of lesser significance in the global thought leadership arena ${ }^{11}$. Nevertheless, the Atlantic Council since the events taking place at Euromaidan has taken a special place on Washington's political stage ${ }^{12}$. The most important Ukrainian politicians: Prime Minister Arseniy Yatsenyuk and President Petro Poroshenko did, after all, speak at the offices of this think tank. They can be viewed as historical appearances for many reasons. On March 12, 2014, Arseniy Yatsenyuk arrived at the Atlantic Council building directly from a meeting in the White House with President Barack Obama, Vice President Joe Biden and Secre-

${ }^{10}$ Such as for example Wolfgang Ischinger, Igor Ivanov, Sam Nunn or Adam Daniel Rotfeld.

${ }_{11}$ As assessed in the Global Go To Think Tanks Index Report ranking mentioned previously in the paper.

12 This is due mainly to the high profile of speakers hosted by the think tank, as the political focus of this organization is very similar to that of both the Brookings Institution and the Carnegie Endowment for International Peace. 
tary of State John Kerry. During his dramatic speech, he appealed to the audience gathered in the Atlantic Council offices for solidarity with Ukraine, which entered into a state of informal war with the Russian Federation (Ukrainian Prime Minister Arseniy Yatsenyuk). Petro Poroshenko spoke in a similar tone on September 18, 2014 (Ukrainian President Petro Poroshenko Speaks at the Atlantic Council).

On the same day, Petro Poroshenko appealed to American congressmen for military support for Ukraine, saying, inter alia, that it is impossible to win a war using blankets ${ }^{13}$. Organization of both speaking opportunities by the Atlantic Council was unprecedented not only in Washington, but throughout the United States. In this manner, the discussed think tank became the key location where local political stakeholders could meet Ukrainian leaders, have an opportunity to hear and see their speeches up close. The speeches of Yatsenyuk and Poroshenko were only part of broader activity of the Atlantic Council aimed at shaping American policy towards the Russian Federation after annexation of Crimea. This think tank also organized a very significant conference Toward a Europe Whole and Free during which political figures such as Joe Biden, John Kerry, Jose Manuel Barroso, Madeleine K. Albright, John McCain, Zbigniew Brzezinski, Linas Linkevičius and Włodzimierz Cimoszewicz made appearances as speakers (Toward a Europe Whole and Free-Agenda - April 29-30, 2014). It is significant that during all panel sessions the conflict in Ukraine was discussed in both a global and transatlantic context. Zbigniew Brzezinski emphasized that "the Ukrainian crisis is the most important challenge to the international systems since the end of the Cold War" (Conversation with Zbigniew Brzezinski: The Eastern Edge of a Europe Whole and Free). Thus, it can be concluded that the Atlantic Council was, in economic terms, the "most active actor on the market" in terms of organization of public events with participation of high-profile American, European and Ukrainian political leaders.

Analyses created by a think tank are also highly important for framing of ideas. Also in this domain, the Atlantic Council plays an important role in the market of ideas, having issued two key reports in 2015: "Preserving Ukraine's Independence, Resisting Russian Aggression: What the United States and NATO Must Do" (in cooperation with Brookings Institution and Chicago Council on Global Affairs) (see Daalder, Flournoy, Herbst, Lodal, Pifer, Stavridis, Talbott, Wald, 2015) and "Hiding in Plain Sight: Putin's War in Ukraine" (see Czuperski,

${ }_{13}$ Petro Poroshenko alluded here to the concept of supplying the Ukrainian army only with light materials, such as blankets or night vision goggles (see Full text of Poroshenko's speech to joint session of US Congress). 
Herbst, Higgins, Polyakova, Wilson, 2015). Both studies are a compendium of important arguments proving the need for the Western world to respond to Russian aggression against Ukraine. Additionally, they provide a number of pieces of evidence and facts important in the information and propaganda war. Let us focus for a moment on one aspect of this activity of the think tank in question. During the annual interview-conversation with citizens of the Russian Federation in 2014, Vladimir Putin said that "(...) There are no Russian units in eastern Ukraine” (Direct Line with Vladimir Putin). However, the Atlantic Council presented evidence of presence of Russian troops in the eastern and southern regions of Ukraine using an interesting and quite unconventional method - namely, satellite photos from the universally available internet service, Google Earth, and photos from social networking sites such as Facebook, WKontaktie (Rus. BКонтакme) ${ }^{14}$, Twitter and YouTube. Materials published on these portals (both photos and video files) contain geolocation data as they are usually recorded on smartphones, which use GPS data. Thanks to this, one can easily trace the location from which they were uploaded. Both Russian and Ukrainian soldiers and local inhabitants often published geo-tagged materials on these sites, which clearly proves that Russian soldiers actually did operate on the territory of Ukraine at the time. In this way, the report by the Atlantic Council "Hiding in Plain Sight: Putin's War in Ukraine" revealed the lies of Vladimir Putin, providing irrefutable evidence not only for use by experts but also politicians from the Western world. This exemplifies how unconventional methodology makes this think tank truly unique, not only on the American soil, but also from a global perspective.

The Atlantic Council therefore enjoys quite a unique positioning compared to other Washington think tanks. It combines the role of an organization dealing with public diplomacy, but also that of an innovative expert organization in analytical studies authored by its experts going beyond the standard models and frameworks. The Atlantic Council certainly defines interesting and new ideas for the American foreign policy, provides alternative scenarios but, like the Brookings Institution and Carnegie Endowment for International Peace, has no significant impact on shaping the decision-making process of the American diplomacy.

\footnotetext{
${ }^{14}$ Local Russian counterpart of Facebook.
} 


\section{Geopolitics - Effectiveness - Delusions}

Referring back to the main topic of the paper, certain conclusions can be drawn regarding the role of American leading think tanks in shaping US foreign policy towards the Russian Federation after annexation of Crimea in March 2014. All analyzed think tanks were active in the US Capital ideas market in terms of trying to frame Washington's response to Moscow's move. Both the Brookings Institution, the Carnegie Endowment for International Peace and the Atlantic Council were able to describe the state of affairs in a professional manner, but rarely provided alternative political and practical solutions. Undoubtedly, the Atlantic Council was the most active think tank in this aspect, both as concerned organization of public events and preparation of important expert studies on US policy towards the Russian Federation. However, the key goal of the paper was to answer the question if and to what extent the analyzed think tanks actually influenced American foreign policy. In this regard, despite multiple limitations of the methodology used, it can be concluded that the real impact of these organizations on decision-making process was negligible. The author is not aware of any direct reference to events organized by the Brookings Institution, the Carnegie Endowment for International Peace or the Atlantic Council or analyses prepared by these think tanks made by representatives of the American administration.

The actual impact of work done by these organization on American policy in this matter may have been limited for a number of reasons. One of them is the nonpartisan nature of the analyzed think tanks - they are not affiliated with any of the American political parties. They do not have an ideological character, unlike for example the Heritage Foundation or the American Enterprise Institute, well-known as partisan Republican think tanks, or the Center for American Progress affiliated with the Democrats. Therefore, their access to influential political figures from both the Republican and Democratic party establishment was limited to - rarely - inviting them to seminars as speakers. Of course, the analyzed think tanks have certain ideological and political sympathies, but these do not translate to a significant extent to either the content they produce or to intimate ties with a specific administration. It is worth noting, however, that also "partisan" think tanks did not play a significant role in shaping the US policy towards the Russian Federation in this case ${ }^{15}$.

${ }^{15}$ Center for American Progress was quoted by politicians of the Democratic party only in reference to its work on internal US policies, never in connection with the US stance towards the Russian Federation after annexation of Crimea. 
Another contributing factor to the weak impact of the analyzed think tanks on US policy towards the Russian Federation are changes in the geopolitical system itself. Think tanks dealing with international affairs significantly gained in importance at the apogee of the Cold War, in the 1960s. They were at the time the intellectual and ideological avant-garde of sorts in the world of foreign policy. Decision-makers themselves sought contact with independent experts who were not only a source of knowledge for them, but also an important inspiration. The analyzed domain of US-Russian political relations, formerly US-Soviet relations, lost in importance after 1991, when the Soviet Union and the Bipolar World collapsed. Since then, the American political elites have concluded that their policy towards the Russian Federation and other former Soviet republics need not be based on in-depth and intricate analyses of think tanks anymore. The "end of history", i.e. triumph of marriage of liberal democracy and market capitalism over authoritarian socialism based on command economy has lessened the significance of think tanks in actual policy making, especially when it comes to foreign policy. In other words, macro-geopolitical changes directly contributed to the steadily diminishing role of think tanks as concerns shaping the United States policy towards the Russian Federation ${ }^{16}$.

Moving on to a quick summary of the paper, it is worth coming back to the question about the nature of changes taking place in contemporary liberal democracies and in the American policy itself. We live in a world of mediocracy, where the speed of information transfer and the need for concise and short "soundbite" opinions - even on the most complex topics - also affect the work of think tanks. The analyzed case study is a proof of this change. The need for a quick response to events unfolding in the southern and eastern parts of Ukraine forced the analyzed organizations to formulate an almost instant response and adjust and re-frame the topics they were dealing with at the time. On the one hand, this show of flexibility on the part of these organizations can be interpreted in a positive light. On the other hand, they all seem to have lost the sense of and focus on their long-term mission of shaping ideas and effecting political change. To rephrase, currently think tanks do not shape policy, but are in fact shaped by politics - both in terms of forms of their activity and the topics they focus on. It is no wonder that arguments used by politicians are closer to shallow Internet summaries than reliable

16 This trend encompasses also the crucial geopolitical reorientation of the United States during presidency of Barack Obama - starting with the "reset" of the US-Russia relations during presidency of Dmitry Medvedev and ending with the "Pivot to Asia", in which the Pacific region was defined as the new main contender in the competition for global economic and political primacy in the future. 
fact-based studies. Most think tanks are aware that the information revolution requires them to change the way they produce materials and provide expertise and analyzes. The new generation of politicians, activists and analysts are all in a sense digital natives, the virtual world is for them a natural environment for creating ideas, content, and showcasing their postulates.

This revolution also obviously affects think tanks, which have to reform their communication to reach this new audience. However, an open question arises: how to present an alternative political vision or a groundbreaking and innovative idea in 280 characters? The matter is even more important with the current President of the United States Donald Trump having repeatedly proven that his approach to politics is almost in no way "compatible" with the traditional one, based on expert knowledge. The results of the US presidential election on November 3, 2020 will be decisive for how much think tanks will be alienated and marginalized in policy-making by the White House and its administration in the next years.

\section{References:}

2019 Global Go To Think Tank Index Report. (2020). Retrieved from: https://repository. upenn.edu/cgi/viewcontent.cgi?article=1018\&context=think_tanks.

Andrew S. Weiss. (2020). Retrieved from: http://carnegieendowment.org/experts/?fa=824.

Brookings Institution. Russia (2020). Retrieved from: https://www.brookings.edu/topic/ russia/.

Czuperski, M., Herbst, J., Higgins, E., Polyakova, A., Wilson, D. (2015). Hiding in Plain Sight: Putin's War in Ukraine. Retrieved from: http://www.atlanticcouncil.org/publications/reports/hiding-in-plain-sight-putin-s-war-in-ukraine-and-boris-nemtsov-sputin-war.

Conversation with Zbigniew Brzezinski: The Eastern Edge of a Europe Whole and Free. (2014). Retrieved from: https://youtu.be/YW3Yj5jLcOs.

Daalder, I., Flournoy, M., Herbst, J., Lodal, J., Pifer, S., Stavridis, J., Talbott, S., Wald, Ch. (2015). Preserving Ukraine's Independence, Resisting Russian Aggression: What the United States and NATO Must Do. Retrieved from: https://www.atlanticcouncil.org/ in-depth-research-reports/report/preserving-ukraine-s-independence-resisting-russian-aggression-what-the-united-states-and-nato-must-do/.

Damon Wilson. (2020). Retrieved from: http://www.atlanticcouncil.org/about/experts/ list/damon-wilson.

Debate: Should the West Arm Ukraine? (2015). Retrieved from: https://youtu.be/5-CpXqBEL8o.

Direct Line with Vladimir Putin. (2015). Retrieved from: http://en.kremlin.ru/events/president/news/49261. 
Eugen Rumer. (2020). Retrieved from: http://carnegieendowment.org/experts/?fa=917.

Euro-Atlantic Security Initiative. (2020). Retrieved from: http://carnegieendowment.org/ specialprojects/EuroAtlanticSecurityInitiativeEASI/

Fiona Hill. (2020). Retrieved from: https://www.brookings.edu/experts/fiona-hill/.

Full text of Poroshenko's speech to joint session of US Congress. (2014). Retrieved from: https:/www.kyivpost.com/article/content/war-against-ukraine/full-text-of-poroshenkos-speech-to-joint-session-of-us-congress-365182.html.

John E. Herbst. (2020). Retrieved from: http://www.atlanticcouncil.org/about/experts/ list/john-e-herbst.

McGann, J.G. (2007). Think Tanks and Policy Advice in the United States. Academics, advisors and advocates. New York: Routledge.

Pifer, S., Talbott, S. (2014). Time to Give Ukraine Defensive Weapons. Retrieved from: http:/www.brookings.edu/research/opinions/2014/09/17-ukraine-military-assistance-pifer-talbott.

Revitalizing NATO: Address by Secretary-General Rasmussen. (2014). Retrieved from: https://youtu.be/pvIf1HIjnG0.

Steven Pifer. (2020). Retrieved from: http://www.brookings.edu/experts/pifers.

Selee, A., (2013). What should think tanks do? A strategic guide to policy impact? Stanford: Stanford University Press.

Toward a Europe Whole and Free - Agenda - April 29-30, 2014. (2014). Retrieved from: http://https://www.atlanticcouncil.org/event/toward-a-europe-whole-and-free/

Transatlantic Ties for a New Generation: A Statesman's Forum with Frank-Walter Steinmeier. (2014). Retrieved from: https://youtu.be/i2-ZGpU_u_k.

Ukrainian President Petro Poroshenko Speaks at the Atlantic Council. (2014). Retrieved from: https://youtu.be/OOCAvqYRbAw.

Ukrainian Prime Minister Arseniy Yatsenyuk. (2014). Retrieved from: https://youtu.be/ewdW0sbyA2g. 